preuve de sensibilité et de bienveillance face à un individu incarnant l'ensemble des traits du bandit qui lutte contre le pouvoir constitutionnel.

SILVIA CORELLI

Sapienza Università di Roma

\title{
De Langeac, Jean.
}

\section{Letters and Papers. Ed. Jan Pendergrass.}

Travaux d'Humanisme et Renaissance 558. Geneva: Droz, 2016. Pp. 643. ISBN 978-2-600-01955-2 (paperback) CFH 98.

A clergyman and diplomat, Jean de Langeac was also a key officer to the French crown. For his patronage of the arts, de Langeac is known as a man of the Renaissance (19). A religious figure, patron, and political official for almost three decades, he travelled to many countries across Europe. His positions and extensive travels resulted in nearly one hundred letters, mission reports and instructions, speeches, expense reports, financial receipts, litigation records, and many other official and administrative documents (20). Of most significance are his letters focusing on diplomatic and military affairs. In this collection of his letters and papers, editor Jan Pendergrass aims to "offer historians a better, more complete understanding" of de Langeac's "role in European affairs than would a standard collection of correspondence only" (20). This edition also contains documents collected from a number of library archives in France and other parts of Europe that so far have been either unpublished or unexamined.

Pendergrass's introductory notes are essential to our understanding of the context, style, and content of each letter and document. They allow readers to see not only the political world of Europe and its officials but also de Langeac's own personal battles in balancing his life as a clergyman and a crown official. As well as a chronology of his life's important events, this edition adds a list of his travels. The bulk of the text is dedicated to over five hundred pages of letters and papers; each is presented in its original format, in French or Latin, with commentary from the editor. If one finds the need for further explanation of terms, people or places, Pendergrass has added extensive footnotes. An extensive bibliography, pointing to disjecta membra manuscripts, adds to the book's value. 
It is important to note that de Langeac's letters were written by one or more official scribes, thus, for the most part, de Langeac is only the official signatory. As Pendergrass argues, the element of style is thus essential in examining the letters and the documents. The "narrative sequence" style of writing speaks of Europe's political conditions, ambassadorial travels, illnesses, and money issues representing a period of constant struggle to create alliances in the everchanging world of Renaissance Europe intertwined with politics and religion $(65,87,103)$. De Langeac's idea was not to impress his readers but rather to inform them of important recent events, at the same time demonstrating the desire to serve. In fact, one form of classic rhetoric that is considered a key feature of Renaissance letter writing — ambiguity — was intentionally avoided by de Langeac and his scribes. However, Pendergrass cautions that often historians of the past have extracted what seems interesting to them while ignoring stylistic elements that are "viewed as verbose, redundant or merely rhetorical" (22). In this aspect, they unintentionally neglect the role of such elements which can help one grasp the meaning of the correspondence. Pendergrass draws our attention to the place of the signature which represents the official position and importance of the writer and the reader. The "narrative sequence" is also considered vital. De Langeac in his correspondence gives the affairs of state precedence over other matters.

The letters and papers Pendergrass has chosen are diverse. Pendergrass rightly argues that examining the letters while keeping in mind the stylistic aspects of writing in early modern France can significantly change the outcome of a historian's examination. The letters and papers are direct and to the point, but a historian of the early modern period can see the growing political influence of the French court, the papal power, involvement of the crown in religious matters, and a period of economic growth in France to strengthen its place in Europe's diplomacy and economic relations. This book can also be a great source for graduate students who are looking for projects in the political and diplomatic relations of Europe during the sixteenth century. While Pendergrass argues that de Langeac should not be considered a humanist just because he was a patron, the lenses of humanism and Renaissance rhetoric will help us grasp the meaning and aim of each letter, thus comprehending its official goal.

ARAZOO FEROZAN

McMaster University 